\author{
NIKOLA GÓRAL \\ Studenckie Koło Naukowe Biologów \\ Wydział Biologii i Biotechnologii \\ Uniwersytet Marii Curie-Skłodowskiej w Lublinie \\ Akademicka 19. 20-033 Lublin \\ E-mail: goral.nikola@gmail.com
}

\title{
PODOBIEŃSTWA I RÓŻNICE MIĘDZY GATUNKAMI BLIŹNIACZYMI: CHOMICZNIKIEM DŻUNGARSKIM PHODOPUS SUNGORUS I CHOMICZNIKIEM ZABAJKALSKIM PHODOPUS CAMPBELLI. BEHAWIOR I FIZJOLOGIA
}

\section{WSTEP}

Chomiczniki, podobnie jak myszy i szczury, zaklasyfikowane zostały do podrzędu myszowatych (Myomorpha) i nadrodziny myszowe (Muroidea). Wyróżnia się rodzinę chomikowatych (Cricetidae), a wśród niej 6 podrodzin: karczowniki, nowiki, bawełniaki, gałęziaki, grzywaki i chomiki (Cricetinae). $\mathrm{Na}$ rodzinę chomików składa się 7 rodzajów i około 300 gatunków (WILSON i REEDER 2005, NEUMANN i współaut. 2006, FEOKTISTOVA i współaut. 2019).

Rodzaj Phodopus jest najstarsza filogenetycznie grupa $\mathrm{w}$ podrodzinie Cricetinae (Ryc. 1). Szacuje się, że oddzielenie tej grupy nastapiło 8,5-12,2 milionów lat temu, natomiast rozdzielenie gatunków Phodopus sungorus (Ryc. 2 a, po lewej) i P. campbelli (Ryc. 2 b, po prawej) miało miejsce około 0,8-1 miliona lat temu (WYNNE-EDWARDS 2003, MEshCHERsKY i FEOKTISTOVA 2009, FeOKTistova i współaut. 2019). Pozycję filogenetyczną tych gatunków ustalono na podstawie analiz dwóch sekwencji pochodzacych $z$ genomu mitochondrialnego (12S rRNA i sekwencji kodujacej cytochrom b) i jednej sekwencji $z$ genomu jądrowego (ekson $28 \mathrm{z}$ sekwencji kodującej czynnik von Willebranda). Wykazano bliskie pokrewieństwo $P$. campbelli $\mathrm{i} P$. sungorus $(\mathrm{MP}=100, \mathrm{NJ}$ $=100, \mathrm{ML}=100, \mathrm{BAP}=1,0)$. Między tymi dwoma gatunkami a należącym do tego samego rodzaju chomicznikiem malutkim Phodopus roborouskii jest wiele istotnych różnic - odrębność $P$. roborovskii została również
\end{abstract}

potwierdzona przez analizy filogenetyczne. Niektórzy badacze sugeruja, że należałoby wydzielić chomicznika malutkiego jako oddzielny rodzaj (NEUMAN i współaut. 2006).

Już od lat 60. wykorzystywano osobniki $P$. sungorus i $P$. campbelli do badań laboratoryjnych $\mathrm{w}$ rosyjskich instytutach badawczych, jednak do późnych lat 80. większość naukowców klasyfikowała je jako jeden gatunek. Poczatkowo rozdzielono je na podgatunki $P$. sungorus sungorus i $P$. sungorus campbelli. Pod koniec lat 60. odkryto pewne różnice $\mathrm{w}$ dwunastej i trzynastej parze chromosomów autosomalnych, a na początku lat 70. wykazano trudności w uzyskiwaniu hybryd, w tym sterylność hybryd męskich w pokoleniu F1, co potwierdzono piętnaście lat później badaniami na dużej grupie zwierząt (FEOKTISTOVA i współaut. 2013).

Hybrydy żeńskie sa płodne (FEOKTISTOVA i współaut. 2019). Dokładniejsze badania wskazuja na nieprawidłowości w parowaniu i rekombinacji chromosomów płciowych u hybryd, ale nie chromosomów autosomalnych (BIKCHURINA i współaut. 2018).

Gatunki te sa bardzo zbliżone fenotypowo i charakteryzują się wieloma cechami wspólnymi, m.in. podobnymi rozmiarami osobników dorosłych i szczeniaków oraz takim samym czasem trwania ciaży (FEOKTISTOVA i współaut. 2019). Oba gatunki maja ciemniejsze futro na grzbiecie i dużo jaśniejsze od strony brzusznej, jaśniejsze zabarwienie futra wokół warg i jasne łapy. Oba gatunki maja także ciemna pręgę na środku 


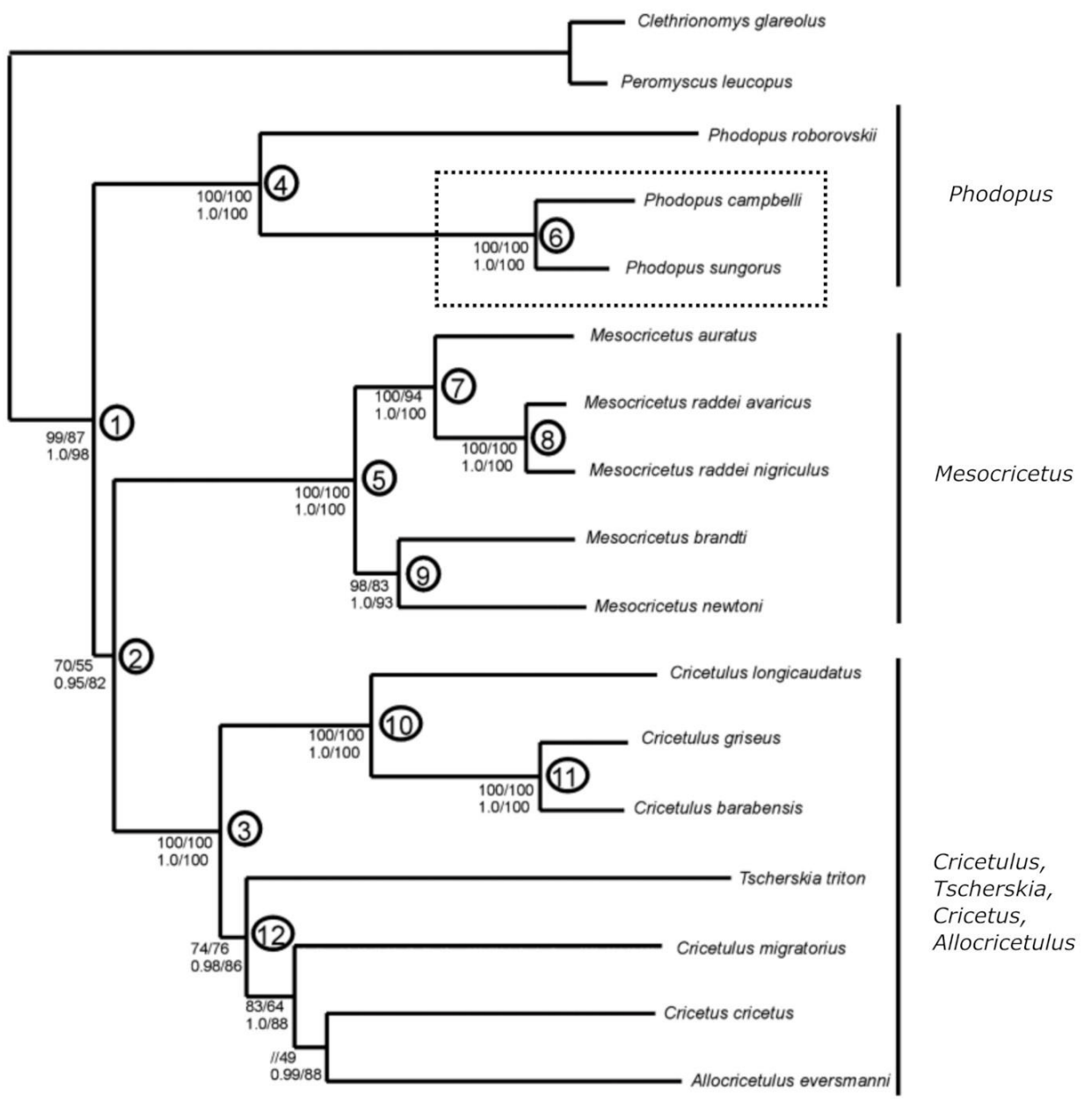

Ryc. 1. Drzewo filogenetyczne sporządzone dla 15 gatunków z podrodziny Cricetinae (NEUMANN i współaut. 2006). Przerywana linia autor zaznaczył pozycję P. campbelli i P. sungorus.
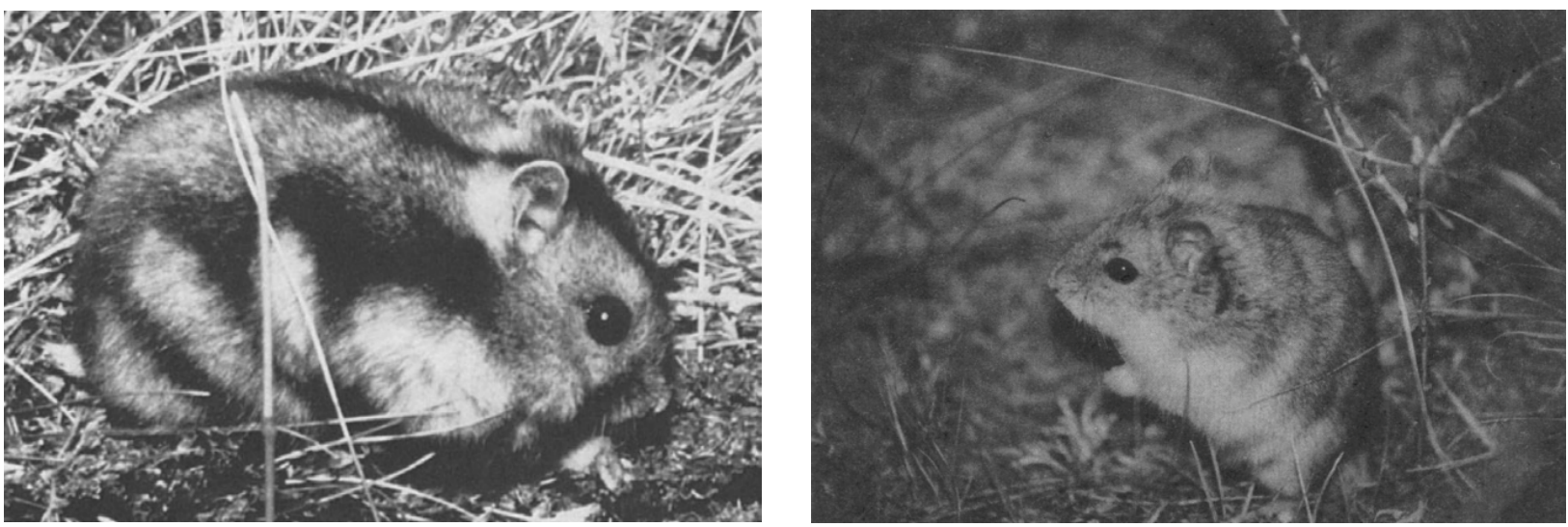

Ryc. 2. Phodopus sungorus (po lewej) i Phodopus campbelli (po prawej) (Ross 1995, 1998).

grzbietu. U P. sungorus pręga ta jest grubsza i dłuższa - sięgająca aż po szczyt głowy. U $P$. campbelli jest cieńsza, ale ostrzej zarysowana. U $P$. sungorus występuje dodatkowo ciemny pas futra przebiegajacy na granicy między częścia brzuszna a grzbietowa - w tym miejscu futro u $P$. campbelli jest jaśniejsze i o lekko żółtawym zabarwieniu. U $P$. sungorus futro brzuszne jest białe, a u $P$. campbelli bardziej popielate. Cecha odróżniającą oba gatunki od $P$. roborouskii sa masywniejsze zęby, dłuższa przerwa między siekaczami. (Ross 1995, 1998; ELLERMAN i współaut. 1943). Ogon jest mocno zreduko- 
wany, o długości mniejszej niż 1/5 długości głowy. Stopy krótkie i szerokie, całkowicie owłosione. Wydatne pazury przednich łap (ELLERMAN i współaut. 1943). Spośród cech morfologicznych, cechą wyróżniająca cały rodzaj Phodopus na tle innych myszowatych i będąca wspólna dla obu opisanych chomiczników, sa stosunkowo krótkie paliczki w tylnych stopach. Cecha ta sprawia, że biegaja dużo wolniej od innych myszowatych (WYNNE-EDWARDS i współaut. 1992).

Wyróżnianie ich jako dwa oddzielne gatunki poparte jest jednak wieloma różnicami w behawiorze i fizjologii, które najprawdopodobniej powstały jako adaptacje do zamieszkiwania w innych strefach klimatycznych (FEOKTISTOVA i współaut. 2019). Bliskie pokrewieństwo filogenetyczne i bardzo duże podobieństwo morfologiczne, przy jednocześnie istniejaccej barierze reprodukcyjnej, to typowe wyznaczniki gatunków bliźniaczych (LinCOLN i współaut. 1998).

\section{SIEDLISKO}

Miejscem występowania obu chomiczników sa wysokie północne szerokości geograficzne - leśno-stepowa strefa środowej Syberii i najbardziej wysunięte na wschód rejony Rosji (Ryc. 3). Opisywane gatunki sa jednak całkowicie allopatryczne i zajmuja wyraźnie odrębne partie tych terenów. P. sungorus spotykany jest na zachodzie i północy, podczas gdy tereny $P$. campbelli obejmuja wschód, w tym północna Mongolię i północne Chiny. Klimat w obu przypadkach jest suchy i chłodny, ale obszary wystepowania $P$. sungorus należa jeszcze do strefy umiar- kowanej, a obszary wystepowania $P$. campbelli - już do strefy kontynentalnej. Klimat w strefie kontynentalnej jest bardziej skrajny i zmienny. Gwałtowne wahania temperatur występuja zarówno w ciagu dnia, jak i sezonowo. Średnie miesięczne temperatury na tych terenach nie przekraczaja $15^{\circ} \mathrm{C}$. Roczne opady nie przekraczaja $210 \mathrm{~mm}$ i aż połowa $z$ nich ma miejsce $w$ krótkim okresie lipca i sierpnia (MÜLLER i współaut. 2015).

Łagodniejszy klimat terenów zamieszkanych przez $P$. sungorus charakteryzuje się miesięcznymi średnimi temperaturami sięgajacymi $20^{\circ} \mathrm{C}$ i rocznymi opadami wynoszacymi około $420 \mathrm{~mm}$, czyli dwa razy większymi niż w przypadku $P$. campbelli. Duże różnice w warunkach środowiskowych przyczyniły się do wykształcenia u tych gatunków różnic morfologicznych, fizjologicznych i behawioralnych (MÜLLER i współaut. 2015).

W okresie rozrodczym w norach P. campbelli utrzymuje się stała temperatura około $18^{\circ} \mathrm{C}$. Poza norami, na powierzchni ziemi, temperatury moga wahać się w przedziale $5-40^{\circ} \mathrm{C}$, przy czym w nocy, kiedy chomiczniki sa aktywne, zwykle wynosza poniżej $10^{\circ} \mathrm{C}$. Osobniki $P$. campbelli sa fizjologicznie i morfologiczne zaadaptowane do bardzo niskich temperatur. Maja powierzchnię ciała bardzo niewielką w stosunku do objętości zarówno uszy, jak i ogon sa małe. Dodatkowa termoregulację zapewnia gruba warstwa futra, sięgająca aż do stóp zwierzęcia (WALTON i WYNNE-EDWARDS 1998). Adaptacje u $P$. sungorus sa podobne, jednak w trakcie rozwoju ontogenetycznego futro rozwija się wolniej i jest dużo cieńsze (NEWKIRK i współaut. 1998). Cechy te ograniczaja utrace ciepła

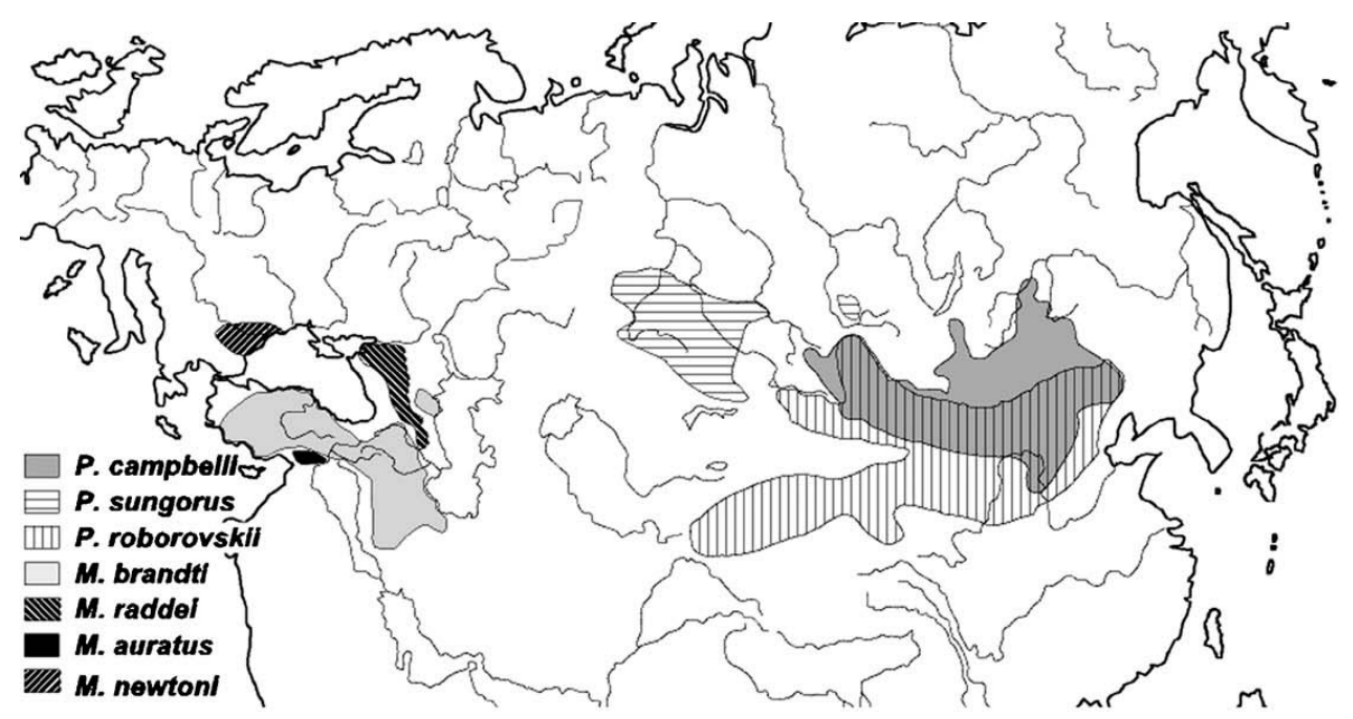

Ryc. 3. Mapa przedstawiajaca zasięgi geograficzne przedstawicieli podrodziny Cricetinae (NEUMANN i współaut. 2006). Zasięgi $P$. roborovskii i $P$. campbelli się częściowo pokrywają. P. sungorus jest allopatryczny względem pozostałych gatunków $z$ rodzaju Phodopus. 
i umożliwiają przeżycie młodych $\mathrm{w}$ bardzo niskich temperaturach (WALTON i WYNNE-EDWARDS 1998), jednak czynia chomiczniki wrażliwymi na wysokie temperatury i latwo ulegajacymi hipertermii (SCRIBNER i WYNNE-EDWARDS 1994 a, b, c). Przy temperaturach wyższych niż $20^{\circ} \mathrm{C}$ chomiczniki traca dużo wody. Wysoka temperatura wplywa negatywnie również na rozwój młodych (WALTON i WYNNE-EDWARDS 1998).

Habitat obu gatunków stanowi zazwyczaj duża otwarta przestrzeń stepów. Jeden i drugi gatunek tworzy populacje o bardzo niewielkim zagęszczeniu. Według niektórych danych zagęszczenie to wynosi do 25 osobnikôw na $1 \mathrm{~km}^{2}$ (WYNNE-EDWARDS i współaut. 1992), a według innych - od 1 do 6 osobników na $1 \mathrm{~km}^{2}$ (RENDON i współaut. 2020). Jest to cecha bardzo charakterystyczna dla rodzaju Phodopus, rzadka u pozostałych gryzoni (WYNNE-EDWARDS i współaut. 1992).

\section{TRYB ŻYCIA, AKTYWNOŚĆ}

Oba gatunki posiadaja pewne cechy charakterystyczne dla ssaków prowadzacych nocny tryb życia. W warunkach laboratoryjnych takie czynności jak korzystanie $z$ kołowrotka czy picie wody, wykonywane sa niemal wyłacznie $\mathrm{w}$ nocy. Od pory dnia zależy również ich temperatura ciała - w nocy wyższa niż w dzień o ok. $1,5^{\circ} \mathrm{C}$. Phodopus sungorus wykazuja jednak krótsza aktywność, a samice tego gatunku, w porównaniu do samic $P$. campbelli, spędzaja mniej czasu na takich aktywnościach, jak czyszczenie się, eksploracja i znakowanie terenu (SCRIBNER i WYNNE-EDWARDS 1994a). Badania wykazały, że osobniki $P$. campbelli budza się jeszcze przed zmrokiem i spędzaja na powierzchni ziemi 2,5 razy więcej czasu niż $P$. sungorus. Phodopus sungorus budza się dopiero po zmroku, czasem nawet długo po zachodzie słońca (WYNNE-EDWARDS i współaut. 1999).

Samice $P$. campbelli odbywaja długie wędrówki, pokonując dobowo kilka razy większe odległości niż przedstawiciele obu płci $P$. sungorus. Samce $P$. campbelli również sa dobrze przystosowane do długich wędrówek - biegaja kilka razy szybciej niż samice tego samego gatunku i przedstawiciele obu płci $P$. sungorus. Obserwacje $\mathrm{w}$ naturze potwierdzane sa wzorami aktywności w laboratorium, mierzonymi jazda w kołowrotku. Tak duża aktywność $P$. campbelli jest kolejna konsekwencja surowych warunków, zmuszających do intensywniejszego poszukiwania pożywienia na dłuższych odległościach niż w przypadku $P$. sungorus (WYNNE-EDWARDS i współaut. 1999).
Ponieważ oba gatunki do pewnego stopnia reaguja na zmianę długości dnia i nocy, wykorzystywane sa do badań nad funkcjonowaniem szyszynki i wpływem sezonowych zmian fotoperiodu na rozmnażanie. Jednak $P$. sungorus jest do tego lepszym modelem jego reakcje sa wyrazistsze, a fizjologia bardziej zależna od fotoperiodu (EBLING 1994). Duża sezonowość i okresowa dużo mniejsza dostępność pokarmu na Syberii wymaga regularnych zmian $\mathrm{w}$ fizjologii $\mathrm{i}$ behawiorze. Chomiczniki nie wykształciły endogennego rytmu okołorocznego. Zamiast tego adaptuja się do sezonowych zmian $\mathrm{w}$ otoczeniu, reagując bezpośrednio na długość dnia i nocy. Uczestniczy w tym układ neuroendokrynny, a szczególna rolę odgrywaja zmiany poziomu melatoniny. W warunkach laboratoryjnych można, zmieniając warunki oświetlenia i temperaturę, sztucznie wpływać na fizjologię tych zwierzat. Skracając czas oświetlania laboratorium, wywołuje się u chomiczników zmianę fenotypu na zimowy (SCHÖTTNER i współaut. 2012, MÜLLER i współaut. 2015).

Różnice $\mathrm{w}$ fenotypie zimowym i letnim sa szczególnie wyraźne w zachowaniach rozrodczych i w poziomie agresji. Okres rozrodczy chomiczników przypada na lato, kiedy dni sa długie. Zima u obu gatunków obserwuje się zmniejszenie jąder (niekiedy aż do całkowitej regresji) i zahamowanie spermatogene$z y$, ale $\mathrm{u} P$. sungorus ma to miejsce już $\mathrm{w}$ drugiej połowie września, a u $P$. campbelli dopiero pod koniec października (MÜLLER i współaut. 2015). Niektóre badania wskazuja jednak, że $P$. campbelli może zachować zdolności reprodukcyjne $\mathrm{w}$ zimie (TIMONIN i współaut. 2006).

$\mathrm{W}$ zimie $\mathrm{u} P$. sungorus poziom agresji jest wysoki, mimo niskiego poziomu hormonów płciowych, które zwykle u innych gatunków przyczyniaja się do występowania zachowań agresywnych. Najprawdopodobniej za wysoką agresję u chomiczników odpowiadaja inne czynniki - możliwe, że jest to reakcja na deficyt jedzenia. Zaobserwowano to zjawisko zarówno u samców, jak i u samic (BAILEY i współaut. 2016, RENDON i wspólaut. 2017).

Wraz $z$ wydłużaniem nocy wydłuża się również czas dobowej aktywności chomiczników. W przypadku $P$. sungorus okres aktywności wydłuża się symetrycznie - budza się wcześniej i zasypiaja później o taki sam odcinek czasu. Inaczej jest u P. campbelli ich rytm jest bardziej nieregularny, niektóre osobniki wydłużaja okres aktywności w okolicach zmierzchu, a inne w okolicach świtu (MÜLler i współaut. 2015).

Skracanie się dnia powoduje u chomiczników zmniejszenie apetytu i przekierowanie metabolizmu na wykorzystywanie re- 

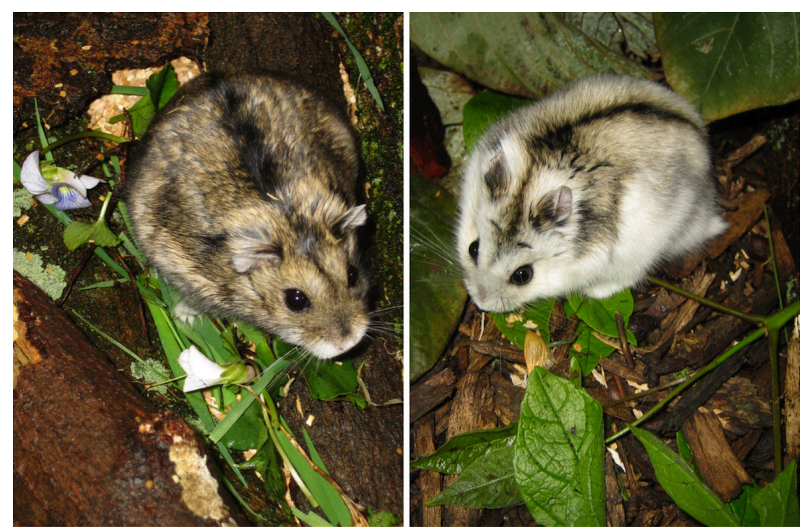

Rys. 4. Letnie (lewa strona) i zimowe (prawa strona) futro u $P$. sungorus (RENDON i współaut. 2017).

zerw energetycznych zawartych w thuszczu w obrębie jamy brzusznej - jest to strategia radzenia sobie $z$ mniejsza dostępnościa pokarmu. W zimie masa ciała chomiczników spada nawet o 44\%, przy czym spadek ten jest większy i zachodzi wcześniej u $P$. sungorus niż u $P$. campbelli (MÜLLER i współaut. 2015). Jest to nietypowe zjawisko, ponieważ mniejsze rozmiary ciała zwiazane sa $z$ mniej korzystnym stosunkiem powierzchni ciała do objętości, przez co zwierzęta traca więcej ciepła. Jednak osobniki mniejsze maja mniejsze zapotrzebowania energetyczne, a utracie ciepła zapobiega bardzo grube zimowe futro.

U P. sungorus zimowe futro różni się nie tylko gęstością, ale też zabarwieniem - jest białe, podczas gdy futro letnie jest szaro-brazowe. U $P$. campbelli można niekiedy zaobserwować lekkie, ale stosunkowo niewielkie rozjaśnienie futra (Ryc. 4) (MÜLLER i współaut. 2015).

\section{DIETA}

O ile ziarna stanowią dużą część diety obu gatunków, to osobniki $P$. sungorus ograniczają się niemal wyłącznie do nich, podczas gdy $P$. campbelli jest gatunkiem w większym stopniu wszystkożernym. Phodopus campbelli i $P$. sungorus sa w stanie ograniczyć pobieranie wody wyłącznie do zawartej w pożywieniu, ale klimat terenów zamieszkiwanych przez P. sungorus umożliwia częste picie wody $\mathrm{w}$ postaci rosy. Taka woda jest bardzo rzadko dostępna dla $P$. campbelli, dla którego częstszym źródłem wody jest mięso larw chrząszczy (SCRIBNER i WYNNE-EDWARDS 1994b).

Gospodarka wodna u $P$. sungorus jest dużo sprawniejsza. Phodopus sungorus lepiej toleruje niski poziom wody w środowisku. Deficyt wody wywiera mniej negatywny wpływ na reprodukcję czy rozwój młodych.
Przy tym ciekawe jest, że mocz u $P$. sungorus jest mniej zagęszczony. Dotychczas nie wyjaśniono, dlaczego mimo mniej zagęszczonego moczu $P$. sungorus lepiej rozwijaja się przy deficycie wody od swoich kuzynów (SCRIBNER i WYNNE-EDWARDS 1994b).

W warunkach laboratoryjnych wykazano subtelne różnice dotyczace skłonności $P$. campbelii i $P$. sungorus do drapieżnictwa. Chomiczniki, podobnie jak większość gryzoni, zwykle uzupełniaja dietę o pokarm pochodzenia zwierzęcego. Najczęściej sa to małe bezkregowce: prostoskrzydłe, motyle i larwy chrzaszczy, jednak najczęściej osobniki osłabione, o obniżonej sprawności, co wskazywałoby raczej na to, że zdolności chomiczników do polowania nie są dobrze rozwinięte (LEVENETS i współaut. 2019).

Strategie polowania u chomiczników sa słabo opisane. Doświadczenia pokazuja, że $P$. campbelli instynktownie reaguja na ofiarę już przy pierwszej styczności $z$ nia, natomiast u $P$. sungorus jest to raczej zdolność wyuczona w trakcie kontaktu $z$ potencjalnym pożywieniem i rzadko wykorzystywana (LEVENETS i współaut. 2019). Różnice te mogą wynikać $z$ większego zapotrzebowania u P. campbelli na pokarm mokry (SCRIBNER i WYNNE-EDWARDS. 1994b).

\section{ZACHOWANIA ROZRODCZE}

Phodopus campbelli sa jednymi $z$ nielicznych ssaków, u których występuje obligatoryjna monogamia, a ponadto samce uczestnicza aktywnie $\mathrm{w}$ opiece rodzicielskiej nad młodymi (WYNNE-EDWARDS 1995, 1998). W przeciwieństwie do nich, $P$. sungorus jest typowym gatunkiem poligamicznym - samice wydają na świat wiele miotów $z$ różnymi samcami. W warunkach laboratoryjnych zdarza się, że samice sa dominujace, czego nigdy nie wykazano u $P$. campbelii (WYNNE-EDWARDS 1987, WYNNE-EDWARDS i LISK 1987).

Różnice ujawniają się także w przebiegu kopulacji. Zakleszczenie trwa pięć razy dłużej u $P$. sungorus i u tego gatunku próba nakłonienia samicy do kopulacji częściej prowadzi do penetracji. Interakcje między osobnikami odmiennej płci sa u P. sungorus dużo bardziej agresywne (WYNNE-EDWARDS i LISK 1987). Samce $P$. sungorus okazuja również więcej agresji względem miotu. Młode samce w małym stopniu różnia się jeszcze zachowaniem od samic, a ich agresja względem młodych zwiększa się wraz $z$ wiekiem. Dorosłe niespółkujace samce często atakuja szczenięta. Do pewnego stopnia zmienia się to po pierwszej kopulacji i doświadczeniach $z$ pierwszym miotem. Samce staja się mniej agresywne i niekiedy moga w jakimś stop- 
niu asystować $\mathrm{w}$ opiece nad młodymi, chociaż nigdy nie sa tak zaangażowane $\mathrm{w}$ opiekę rodzicielska jak samce $P$. campbelli (GIBBER i współaut. 1984). Niektóre badania zaprzeczaja fakultatywnej opiece rodzicielskiej ze strony samców $P$. sungorus wskazując, że nawet takie stresory jak skrócenie fotoperiodu czy duży wzrost temperatury nie zwiększaja częstości opiekuńczych zachowań u samców tego gatunku. Uległość samicy również nie wywiera takiego wpływu (TIMONIN i WYNNE-EDWARDS 2006).

Samce $P$. campbelli współuczestnicza w wychowywaniu młodych, a ich rola jest dwojaka. Po pierwsze pośrednio wpływaja na fizjologię samic. Im dłuższy bezpośredni kontakt samicy $z$ młodymi, tym większe prawdopodobieństwo wystapienia u niej hipertermii. Samiec, zajmując się potomstwem, odciąża samice i pozwala jej na wyregulowanie temperatury ciała (WALTON i WYNNE-EDWARDS 1998).

Drugi, bezpośredni wpływ, zwiazany jest $z$ wysoce opiekuńczymi zachowaniami względem młodych, nie tylko $\mathrm{w}$ porównaniu do $P$. sungorus, ale również na tle większości poznanych gryzoni. Tuż przed narodzinami pierwszego miotu, zanim jeszcze dojdzie do pierwszego kontaktu $z$ młodymi, przechodza serię przemian hormonalnych, w wyniku których zaczynaja wykazywać liczne zachowania ojcowskie, m. in. wylizuja płyn owodniowy i ułatwiają wyjście szczeniaków $z$ kanału rodnego przy użyciu siekaczy i łap. Zaobserwowano także wylizywanie nozdrzy młodych, aby je oczyścić i tym samym ułatwić pierwsze oddechy. Oczyszczaja szczeniaki $z$ pozostałości błon płodowych i zjadaja łożysko. Ponadto pomagaja samicom $\mathrm{w}$ opiece pilnujac, aby potomstwo nie oddalało się zbyt daleko od gniazda i przynoszac pożywienie $\mathrm{w}$ workach policzkowych (JONES i WYNNE-EDWARDS 2000). Zachowania opiekuńcze u samców $P$. campbelii prawdopodobnie sa wrodzone i nie wymagaja zewnętrznych czynników wyzwalajacych, takich jak np. zapachowe, dźwiękowe czy wizualne wskazówki ze strony ciężarnej samicy (JONES i WYNNE-EDWARDS 2001).

$\mathrm{U} P$. campbelli wykazano, że samice $\mathrm{w}$ wyborze partnera kieruja się $\mathrm{w}$ mniejszym stopniu stanem zdrowia samca, czy innymi czynnikami świadczacymi o dobrych genach, a raczej cechami, które czynia ich potencjalnie dobrymi ojcami dla młodych. Istotne jest zachowanie samca podczas kopulacji. Samice unikaja tych samców, które w agresywny sposób próbowały nakłonić je do kopulacji (ROGOVIN i współaut. 2017).

Samice obu gatunków bardzo agresywnie bronia swoich młodych, czyli wykazuja wysoka tzw. agresje matczyna (GAMMIE i NELSON 2005).
Zmiana poziomu poszczególnych hormonów płciowych w cyklu rujowym u $P$. sungorus jest podobna jak u innych gryzoni. U $P$. campbelli zachodzi inaczej, co może być zwiąane $z$ dwurodzicielskim modelem opieki nad młodymi (MCMILLAN i WYNNE-EDWARDS 1998).

U obu chomiczników sezon reprodukcyjny występuje w tym samym czasie (NEWKIRK i współaut. 1997). Jest on krótki, dlatego oba gatunki maja bardzo szybki cykl reprodukcyjny. Miot odstawiany jest niezwykle szybko, co pozwala zwierzętom w krótkim czasie po narodzinach pierwszego miotu wydać na świat drugi (SCRIBNER i WYNNE-EDWARDS 1994a, c). Ciaża trwa tylko 18 dni i natychmiast po wydaniu na świat potomstwa samica jest $\mathrm{w}$ stanie ponownie zajść w ciażę. Od pierwszego krycia do narodzin drugiego miotu może minać jedynie 36 dni. Okres ten jest taki sam u obu gatunków, mimo że szczenięta $P$. sungorus szybciej uzyskuja termiczna niezależność od matki. $\mathrm{W}$ niektórych warunkach opóźnienie $\mathrm{w}$ narodzinach drugiego miotu może wystapić w wyniku tzw. diapauzy poimplantacyjnej. Jest to zjawisko bardzo rzadkie u ssaków, prawdopodobnie występuje jeszcze tylko u nietoperzy (NEWKIRK i współaut. 1997).

Młode obu gatunków rodza się podobnej wielkości i wagi. Szczeniaki $P$. sungorus rozwijaja się dużo szybciej, wcześniej osiagając duże rozmiary i niezależna termoregulację. Ich matka szybciej pozostawia je same w gnieździe (NEWKIRK i współaut. 1998). Kolejną różnica między tymi gatunkami jest inna dynamika struktury miotu - u $P$. campbelli poszczególne dojrzewające szczeniaki stają się bardzo zróżnicowane wielkością, natomiast u $P$. sungorus młode rosna równomiernie, osiagajac podobne rozmiary. Prawdopodobnie zwiazane jest to $z$ innym modelem opieki nad młodymi. U P. sungorus samice inwestuja tyle samo zasobów w każdego potomka $\mathrm{w}$ miocie, $\mathrm{w}$ przeciwieństwie do $P$. campbelli (STULBERG i WYNNE-EDWARDS. 1998). Młode $P$. sungorus, mimo szybkiego osiagania samodzielnej termoregulacji, nie zaprzestaja gwałtownie rosnać, co sugeruje, że wydatki energetyczne poniesione na termoregulację sa $\mathrm{w}$ jakiś sposób rekompensowane. U P. campbelli wzrost zostaje zahamowany aż $\mathrm{w} 44 \% \mathrm{w}$ momencie osiagnięcia przez szczeniaki samodzielności termoregulacyjnej - mechanizm kompensacji nie jest u nich obecny (NEWKIRK i współaut. 1998).

\section{ZACHOWANIA SPOŁECZNE}

Oba gatunki rozróżniaja się nawzajem za pomoca węchu, wyraźnie preferując zapach przedstawicieli własnego gatunku. Najpraw- 
dopodobniej jest to umiejętność wyuczona, ponieważ osobniki hodowane $z$ przedstawicielami drugiego gatunku maja odwrócone preferencje (VASILIEVA i współaut. 2001). Bariera rozrodcza oparta na komunikacji chemicznej jest słabo wykształcona (FEOKTISTOVA i współaut. 2007).

Oba chomiczniki maja 4 typy gruczołów zapachowych, dzięki którym znaczą swój teren. Sa to: gruczoł łojowy na brzuchu, gruczoł piżmowy znajdujacy się na pyszczku, gruczoły Hardera i gruczoły znajdujące się za uszami. Gruczoł piżmowy ma za zadanie znaczyć zapachem pożywienie noszone przez chomicznika w torebkach policzkowych. Samice chomiczników znaczą teren również wydzielina $z$ pochwy. Pewna rolę $w$ znaczeniu terenu odgrywa również mocz i kał (WYNNE-EDWARDS i współaut. 1992). Mocz tych gatunków ma podobny profil substancji lotnych, jednocześnie mocno różniący się od profilu moczu $P$. roborovskii (SOINI i współaut. 2005).

Phodopus campbelli znakuja teren ponad dwukrotnie częściej od $P$. sungorus. Samice obu gatunków znakują równie intensywnie każdy teren, na którym się znajda, natomiast samce częściej znakuja miejsca w pobliżu terytorium samic (WYNNE-EDWARDS i LISK 1987). Samce $P$. campbelli znakuja intensywnie również te miejsca, w których ich terytorium graniczy $z$ terytoriami innych samców. U samic zaobserwowano tendencję do wybierania miejsc osłoniętych przed opadami przez trawy i krzewy, co zapewnia śladom większą trwałość (WYNNE-EDWARDS i współaut. 1992).

Wiele danych wskazuje na wystepowanie w naturze odmiennych struktur populacji tych dwóch gatunków. W przypadku $P$. campbelli terytoria osobników tej samej płci sa ściśle oddzielone, podczas gdy populacje $P$. sungorus sa bardziej zageszczone i kontakty między osobnikami tej samej płci częstsze. Podobnych wniosków dostarczaja obserwacje w laboratorium. Między dorosłymi niespokrewnionymi osobnikami tej samej płci $P$. campbelii rzadko obserwowano bezpośredni kontakt, w przeciwieństwie do $P$. sungorus, u których zdarza się tworzenie struktur hierarchicznych (WYNNE-EDWARDS i LISK 1986).

W warunkach laboratoryjnych u chomiczników również zaobserwowano bardzo wyraźne różnice w wewnątrzgatunkowych stosunkach osobników tej samej płci i gatunku. Samce P. campbelli były agresywniejsze niż $P$. sungorus wobec innych samców swego gatunku, zadajacc im niekiedy poważne rany. U samic było odwrotnie - to samice $P$. sungorus zachowywały się bardziej agresywnie względem innych samic. Mimo innego poziomu agresji u osobników różnych płci, P. campbelli charakteryzują się ogólnie większa agresją niż $P$. sungorus i sa w stanie walczyć $z$ innymi osobnikami aż do śmierci któregośs $z$ nich, podczas gdy u $P$. sungorus wysteppuje zahamowanie agresji, gdy drugi osobnik okaże uległość (WYNNE-EDWARDS i LISK 1986)

Opisywane gatunki różnia się strategia atakowania przeciwnika. Na strategię ataku $P$. campbelli składa się w dużym stopniu drapanie przeciwnika i ruchy przypominające ciosy bokserskie, które u $P$. sungorus sa rzadsze. Phodopus sungorus atakuja ruchem precyzyjnie skierowanym w stronę wrażliwych tkanek przeciwnika: w brzuch lub w bok (GAMMIE i NELSON 2005). Badania nad młodymi $P$. campbelli wykazały, że podczas zabawy około 70\% ataków kierowanych jest w stronę pyska, a pozostała część w stronę czubka głowy lub zadu. W przeciwieństwie do zabawy, w trakcie poważnych walk między osobnikami ciosy $w$ pysk niemal nie występuja, a celem większości ataków jest czubek głowy i zad (PELLIS i PELLIS 1989).

Chomiczniki inaczej reagują na obecność zagrożenia: u P. campbelli odnotowano wyższy niż u $P$. sungorus poziom stresu fizjologicznego w reakcji na zapach drapieżnika (FEOKTISTOVA i współaut. 2007).

\section{PODSUMOWANIE}

Mimo bliskiego pokrewieństwa i dużego podobieństwa w morfologii, $P$. campbelli i $P$. sungorus różnią się istotnie fizjologia i behawiorem. Subtelne różnice w klimacie zadecydowały o odmiennym kierunku ewolucji tych gatunków. Wytworzyły się między nimi częściowe mechanizmy izolacji rozrodczej. Również analizy molekularne potwierdzają ich status jako odrębnych gatunków. Phodopus campbelli posiada wiele cech unikatowych wśród gryzoni, a nawet wśród ssaków. Jest to gatunek obligatoryjnie monogamiczny, z opieka dwurodzicielską. Występuje u niego fakultatywnie diapauza poimplantacyjna. Tak duża specjalizacja, mocno odróżniajaca jeden gatunek $z$ grupy siostrzanej, jest czymś wyjątkowym i wymagajacym dokładnego zbadania.

\section{Streszczenie}

Chociaż osobniki Phodopus sungorus i P. campbelli były wykorzystywane do badań laboratoryjnych już od lat 60., do późnych lat 80. klasyfikowano je jako jeden gatunek. Dopiero analizy genetyczne i badania nad hybrydami jednoznacznie potwierdziły ich status dwóch oddzielnych gatunków. Gatunki te sa bardzo zbliżone fenotypowo i charakteryzuja się wieloma cechami wspólnymi, m.in. podobnymi rozmiarami osobników dorosłych i szczeniaków, takim samym czasem trwania ciąży. Mimo bliskiego pokrewieństwa i dużego podobieństwa $\mathrm{w}$ 
morfologii, $P$. campbelli i $P$. sungorus różnia się istotnie fizjologia i behawiorem, co prawdopodobnie wynika $z$ zamieszkiwania innych stres klimatycznych. Pochodzacy ze strefy kontynentalnej $P$. campbelli posiada wiele cech unikatowych wśród gryzoni, a nawet wśród ssaków. Jest to gatunek obligatoryjnie monogamiczny, $z$ opieka dwurodzicielska. Występuje u niego fakultatywnie diapauza poimplantacyjna. Tak duża specjalizacja, mocno odróżniająca jeden gatunek $z$ grupy siostrzanej, jest czymś wyjątkowym i wymagającym dokładnego zbadania.

\section{LITERATURA}

Bailey A. M., Rendon N. M., O’Malley K. J., DeMAS G. E., 2016. Food as a supplementary cue triggers seasonal changes in aggression, but not reproduction, in Siberian hamsters. Physiol. Behav. 167, 298-308.

BiKChURINA T. I., TishaKova K. V, Kizilova E. A., Romanenko S. A., Serdyukova N. A., TORGASHEVA A. A., Borodin P. M., 2018. Chromosome synapsis and recombination in male-sterile and female-fertile interspecies hybrids of the dwarf hamsters (Phodopus, Cricetidae). Genes 9, 227.

EBLING F. J. P., 1994. Photoperiodic differences during development in the dwarf hamsters Phodopus sungorus and Phodopus campbelli. Gen. Comp. Endocrinol. 95, 475-482.

Ellerman J. R., HAYMan R. W., HolT G. W. C. 1943. The families and genera of living rodents, with a list of named forms (1758-1936). Vol. II. Muridae. British Museum (Natural History).

FEOKTISTOVA N. Y., NAIDENKO S. V., KROPOTKINA M. V., Bovin P. M., 2007. Comparative analysis of the effect of predator odor on morphological and physiological parameters $f$ adult male campbell hamsters (Phodopus campbelli) and dwarf hamsters (Phodopus sungorus). Rus. J. Ecol. 38, 426-429.

Feoktistova N. Y., Chernova O. F., MeshCHeRSKII I., G. 2013. Decorative forms of hamsters of the genus Phodopus (Mammalia, Cricetinae) analysis of genetic lines distribution and features of hair changes. Biol. Bull. Rev. 3, 5772.

FeokTistova N. Y., KRopotkina M. V., PotashniKOVA E. V., GuREeVA A. V., Kuznetsova E. V., KuzNetsova E. V., Surgov A.V., 2019. Speciation in allopatric species of the hamster subfamily Cricetinae (Rodentia, Cricetidae). Biol. Bull. Rev. 9, 230-242.

Gammie S. C., NELSON R. J., 2005. High maternal aggression in dwarf hamsters (Phodopus campbelli and P. sungorus). Agressive Beh. 31, 294-302

Gibber J. R., Piontkiewitz Y., TERKEL J., 1984. Response of male and female Siberian hamsters towards pups. Beh. Neural Biol. 42, 177-182.

JoNES J., WYNNE-EDWARDS K. E., 2000. Paternal hamsters mechanically assist the delivery, consume amniotic fluid and placenta, remove fetal membranes, and provide parental care during the birth process. Hormones Behav. 37, 116-125.

JONES J., WYNNE-EDWARDS K. E., 2001. Paternal behaviour in biparental hamsters, Phodopus campbelli, does not require contact with the pregnant female. Anim. Behav. 62, 453-464.

LeVEnets J. V., PANTEleEva S. N., Reznikov ZH. I., GUREEVA A. V., FEOKTISTOVA N. Y., SUROV A. V., 2019. Experimental comparative analy- sis of hunting behavior in four species of Cricetinae hamsters. Biol. Bull. 46, 1182-1191.

Lincoln R., Boxshall G., Clark P., 1998. A Dictionary of Ecology, Evolution and Systematics. Cambridge University Press, Cambridge, United Kingdom.

MCMillan H. J., WynNE-EDWARDS K. E., 1998. Evolutionary change in the endocrinology of behavioral receptivity: divergent roles for progesterone and prolactin within the genus Phodopus. Biol. Reproduct. 59, 30-38.

MEshCHERSKY I. G., FEOKTISTOVA N. Y., 2009. Intraspecific organization of dwarf hamsters Phodopus campbelli and Phodopus sungorus (Rodentia: Cricetinae) basing on mtDNA analysis. Doklady Akademii Nauk 424, 279-282.

MÜlLER D. J., HAUER J., SCHÖTTNER K., FRITZSCHE P., WEINERT D., 2015. Seasonal adaptation of dwarf hamsters (Genus Phodopus): differences between species and their geographic origin. J. Comp. Physiol. 185, 917-930.

NEUMANN K., MichauX J., LeBedeV V., 2006. Molecular phylogeny of the Cricetinae subfamily based on the mitochondrial cytochrome $b$ and 12S rRNA genes and the nuclear vWF gene. Mol. Phylogen. Evol. 39, 135-148.

NEWKIRK K. D., MCMillan H. J., WynNe-EDWARDS K. E., 1997. Length of delay to birth of a second litter in dwarf hamsters (Phodopus): evidence for post-implantation embryonic diapause. J. Exp. Zool. 278, 106-114.

NEWKirk K. D., Cheung B. L., SCRIBNer S. J., WYNNE-EDWARDS K. E., 1998. Earlier thermoregulation and consequences for pup growth in the Siberian versus Djungarian dwarf hamster (Phodopus). Physiol. Behav. 63, 435-443.

Pellis S. M., Pellis V. C., 1989. Targets of attack and defense in play-fighting of the Djungarian hamster Phodopus campbelli: links to fighting and sex. Aggresive Behav. 15, 217 234.

Rendon N. M., Amez A. C., Proffitt M. R., BAUSERMAN E. R., DEMAS G. E., 2017. Aggressive behaviours track transitions in seasonal phenotypes of female Siberian hamsters. Funct. Ecol. 31, 1071-1081.

Rendon N. M., Petersen C. L., Munley K. M., Amez A. C., Boyes D. L., Kingsbury M. A., DEMAS G. E., 2020. Seasonal patterns of melatonin alter aggressive phenotypes of female Siberian hamsters. J. Neuroendocrinol., doi:10.1111/jne.12894.

Rogovin K. A., HRUSHCHOVA A. M. K., HeKarova O. N. S., VAsilieva N. A., 2017. Females choose gentle, but not healthy or macho males in Campbell dwarf hamsters (Phodopus campbelli Thomas 1905). Curr. Zool. 63, 545-554.

Ross P. D., 1995. Phodopus campbelli. Mammalian Spec. 503, 1-7.

Ross P. D., 1998. Phodopus sungorus. Mammalian Spec. 595, 1-9.

SCHÖTTNER K., SCHMIDT M., HERING A., SCHATZ J., WEINERT D., 2012. Short-day response in Djungarian hamsters of different circadian phenotypes. Chronobiol. Int. 29, 430-442.

SCRIBNER S. J., WYNNE-EDWARDS K. E., 1994a. Disruption of body temperature and behavior rhythms during reproduction in dwarf hamsters (Phodopus). Physiol. Behav. 55, 361369.

SCRIBNER S. J., WYNNE-EDWARDS K. E., 1994b. Moderate water restriction differentially constrains reproduction in two species of dwarf hamster (Phodopus). Canad. J. Zool. 72, 1589-1596. 
SCRIBNER S. J., WYNNE-EDWARDS K. E. 1994c. Thermal constraints on maternal behavior during reproduction in dwarf hamsters (Phodopus). Physiol. Behav. 55, 897-903.

Soini H. A., Wiesler D., APFElbach R., KöNig P., VASILIEVA N. Y., NovotnY M. V., 2005. Comparative investigation of the volatile urinary profiles in different phodopus hamster species. J. Chem. Ecol. 31, 1125-1143.

STUlBeRG S. E., WyNnE-EDWARDS K. E., 1998. Maternal and pup contributions to different patterns of pup growth in Phodopus species. Physiol. Behav. 64, 715-722.

TIMONIN M. E., WYNNE-EDWARDS K. E., 2006. Neither reduced photoperiod, nor female-related social cues, nor increased maternal thermal stress result in a paternally responsive Phodopus sungorus male. Physiol. Behav. 88, 309316.

Timonin M. E., Place N. J., Wanderi E., Wynne-EDWARDS K. E., 2006. Phodopus campbelli detect reduced photoperiod during development but, unlike Phodopus sungorus, retain functional reproductive physiology. Reproduction 132, 661-670.

Vasilieva N., Yu., Lai S.-C., Petrova E. V., JohnSTON R. E., 2001. Development of species preferences in two hamsters, Phodopus campbelli and Phodopus sungorus: efects of cross-fostering. Ethology 107, 217-236.

WALTON J., WYNNE-EDWARDS K. E., 1998. Paternal care reduces maternal hyperthermia in Djungarian hamsters (Phodopus campbelli). Physiol. Behav. 63, 41-47.

WILSON D. E., REEDER D. M., 2005. Mammal Species of the World. A Taxonomic and Geographic Reference. Johns Hopkins University Press.
WYNNE-EDWARDS K. E., 1987. Evidence for obligate monogamy in the Djungarian hamster, Phodopus campbelli: pup survival under different parenting conditions. Behav. Ecol. Sociobiol. 20, 427-437.

WYNNE-EDWARDS K. E., 1995. Biparental care in Djungarian but not Siberian dwarf hamsters (Phohpus). Animal Behav. 50, 1571-1585.

WYNNE-EDWARDS K. E., 1998. Evolution of parental care in Phodopus: Conflict between adaptations for survival and adaptations for rapid reproduction. Am. Zool. 38, 238-250.

WYNNE-EDWARDS K. E., 2003. From dwarf hamster to daddy: the intersection of ecology, evolution, and physiology that produces paternal behavior. Adv. Study Behav. 32, 207261.

WYNNE-EDWARDS K. E., LISK R. D., 1986. Behavioral interactions differentiate Djungarian (Phodopus campbelli) and Siberian (Phodopus sungorus) hamsters. Canad. J. Zoology 65, 2229-2235.

WYNNE-EDWARDS K. E., LISK R. D., 1987. Male-female interactions across the female estrous cycle: a comparison of two species of dwarf hamster (Phodopus campbelli and Phodopus sungorus). J. Comp. Psychol. 101, 335-344.

WYNNE-EDWARDS K. E., SUROV A. V., TElitZinA A. Y., 1992. Field studies of chemical signalling: direct observations of dwarf hamsters (Phodopus) in Soviet Asia. Chem. Signals Vertebrates, doi: 10.1007/978-1-4757-9655-1_74.

WyNNE-EDWARDS K. E., SUROV A. V., TELITZINA A. Y, 1999. Differences in endogenous activity within the genus Phodopus. J. Mammal. 80, 855-865.

KOSMOS Vol. 70, 4, 711-719, 2021

NiKOLA GÓRAL

Students Society of Biologists, Faculty of Biology and Biotechnology, Maria Curie-Skłodowska University in Lublin, Akademicka 19. 20-033 Lublin, E-mail: goral.nikola@gmail.com

SIMILARITIES AND DIFFERENCES BETWEEN CRYPTIC SPECIES OF HAMSTERS: PHODOPUS SUNGORUS AND PHODOPUS CAMPBELLI. BEHAVIOR AND PHYSIOLOGY

Summary

Although Phodopus sungorus and P. campbelli have been used for laboratory research since the 1960s, they were classified as a single species until the late 1980s. Only genetic analyzes and research on hybrids unequivocally confirmed their status as two separate species. These species are phenotypically very similar and are characterized by many common features, including similar sizes of adults and puppies, same duration of pregnancy. Despite the close relationship and great similarity in morphology, P. campbelli and $P$. sungorus differ significantly in physiology and behavior, which is probably the consequence of inhabiting different climatic zones. Originating from the continental zone, P. campbelli has many features that are unique among rodents and even among mammals. It is an obligatorily monogamous species with two-parent care. It has facultative post-implantation diapause. Such an advanced specialization, strongly distinguishing one species from its sister group, is unique and requires further careful study.

Key words: adaptations, Cricetinae, cryptic species, Phodopus, speciation 